\title{
Restless Leg Syndrome
}

\author{
J.M.S. Pearce \\ Emeritus Consultant Neurologist, Department of Neurology, Hull Royal Infirmary, Hull, UK
}

Restless leg syndrome is characterised by: (1) a 'compulsive' restlessness or need to move the legs, often associated with paraesthesiae or dysaesthesiae, (2) symptoms at rest or disturbing sleep, quickly but temporarily relieved by standing and walking, (3) nocturnal worsening of symptoms. Additionally, $75 \%$ of patients also experience periodic limb movement disorder characterized by involuntary leg twitching or jerking movements during sleep, which typically occur every 10-60 s throughout the night.

Thomas Willis [1] described the syndrome in 1672, and in the 1685 edition of his textbook wrote,

'Wherefore to some, when being a Bed they betake themselves to sleep, presently in the Arms and Leggs, Leapings and Contractions of the Tendons, and so great a Restlessness and Tossings of their Members ensue that the diseased are no more able to sleep than if they were in a Place of the greatest Torture'.

Of historical interest is a passage in the English translation of the second edition of Romberg's [2] celebrated A Manual of the Nervous Diseases of Man, written in 1853:

“"Anxietas tibiarum”, a sense of painful restlessness in the lower extremities, especially in the legs and feet. "The patient" did not know what to do with them (...) though there was relief by change of position'.

This is plainly recognisable as the same syndrome as that later so beautifully portrayed by Ekbom. In 1861 Wittmaack called the disorder 'anxiety tibiarum' and related it to hysteria [3].

\section{KARGER}

Fax +4161306 1234 E-Mail karger@karger.ch www.karger.com

\section{S. Karger AG, Basel 0014-3022/05/0534-0206\$22.00/0}

Accessible online at:

www.karger.com/ene

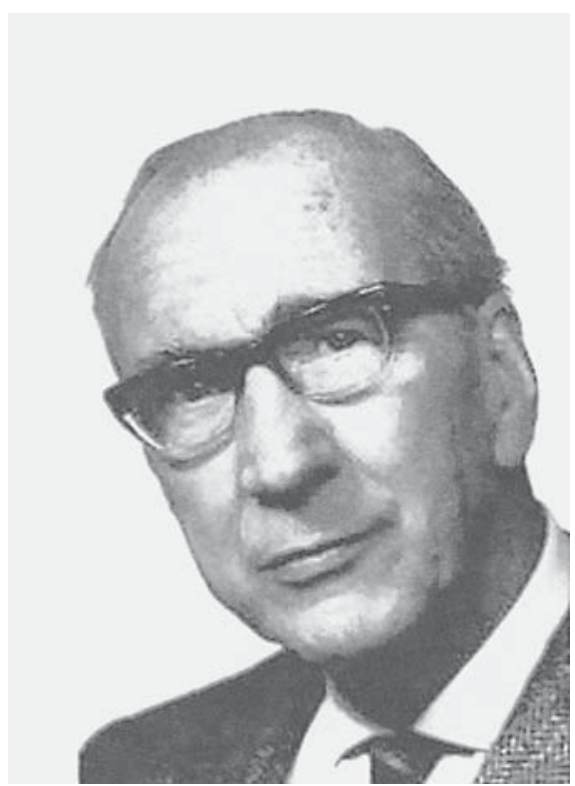

K.A. Ekbom.

'A characteristic feeling is that from older anxietas tibiarum: a strange but descriptive compulsion to move has invaded the legs of the inflicted person. Every moment sees the legs brought into a different position; drawn up, stretched out, abducted, spread apart and crossed over one another. However, these movements are not sudden or violent, rather they are slow, mindful as if it were of eventually finding the one position that will give the most relief. In every strange description of the nervous tension of hysteria one often also finds this train of involuntary agitation displayed in the legs and feet. The same thing also occurs however elsewhere without
J.M.S. Pearce

304 Beverley Road

Anlaby, East Yorks HU10 7BG (UK) 
one being able to find a definite cause (...) the condition lasts approximately a quarter of an hour'.

Hermann Oppenheim [4] was the first to define the disease as a neurological illness and the first to recognize a familial component in his Lehrbuch der Nervenkrankheiten. He noted,

'Restlessness in the legs is a special kind of subjective paralgesia. It can become an agonizing torture, lasting for years or decades and can be passed on and occur in other members of the family'.

The term 'Ekbom's syndrome' [5] is due to several papers by Karl Axel Ekbom [6-8]:

'Asthenia crurum paraesthetica ('irritable legs'). A new syndrome consisting of weakness, sensation of cold and nocturnal paraesthesia in legs, responding to a certain extent to treatment with priscol and doryl'.

In his 1945 publication, Ekbom presented eight cases [7]. He wrote:

'A clinical study of a hitherto overlooked disease in the legs characterized by peculiar paraesthesia, pain and weakness and occurring in two main forms, asthenia crurum paraesthetica and asthenia dolorosa'.

His work distinguished two forms, one with paraesthesiae, the other painful:

(1) 'Asthenia crurum paraesthetica' (which he translated as irritable legs), and

(2) 'Asthenia crurum dolorosa'.
Ekbom later [7] settled for plain 'restless legs syndrome'. It is associated with iron deficiency [9], pregnancy, phenothiazines, barbiturate withdrawal, diabetes, uraemia, and respiratory failure. Sudden jerks on falling asleep may be observed also in otherwise normal persons. Probably heterogeneous, Ekbom's syndrome can occur as a familial condition transmitted as an autosomal dominant trait. Spillane et al. [10] described a similar condition of 'painful legs and moving toes' relieved by sympathetic block with local anaesthetic.

In addition to the unproven value of modifying the intake of alcohol, caffeine and tobacco, symptomatic treatment is useful but benefits are variable and may wear off. Drugs tried include: dopaminergics, benzodiazepines, codeine, and carbamazepine.

Despite much erudite speculation, the aetiology [11] remains an enigma. When compared to normal controls, patients show decreased total sleep time, increased wakefulness, and frequent nocturnal awakenings, increased sleep stage S1, decreased S2 and increased stage shifts. But these may be epiphenomena.

New research with familial early-onset restless legs has shown two distinct genetic linkages - at $12 \mathrm{q}$ in a Canadian family and 14q13-q21 in an Italian family [12].

\section{Conclusion}

Restless leg syndrome appears to be an enigmatic disorder probably influenced by heterogeneous environmental and genetic factors that may work through a variety of so far ill-defined neurochemical systems.

\section{References}

1 Willis T: De anima brutorum. London, Davis, 1672. (See also Willis T: The London Practice of Physick: Or the Whole Practical Part of Physick Contained in the Works of Dr. Willis. London, Bassett Crooke, 1685, p 404.)

2 Romberg MH: Lehrbuch der Nervenkrankheiten des Menschen, vol 1. Berlin, Duncker, 1846.

3 Wittmaak T: Pathologie und Therapie der Sensibilitäts-Neurosen; in Wittmaak T: Lehrbuch der Nervenkrankheiten. Part 1: Pathologie und Therapie der sensiblen Neurosen. Leipzig, Schäfer, 1861.
4 Oppenheim H: Lehrbuch der Nervenkrankheiten, ed 7. Berlin, Karger, 1923, p 1774.

5 Pearce JMS: Romberg and Ekbom's restless leg syndrome. J Neurol Neurosurg Psychiatry 1988;51:1497.

6 Ekbom KA: Asthenia crurum paraesthetica ('Irritable Legs'). A new syndrome consisting of weakness, sensation of cold and nocturnal paraesthesia in the legs, responding to a certain extent to treatment with priscol and doryl; a note on paraesthesia in general. Acta Med Scand 1944;118:197-209.

7 Ekbom KA: Restless legs syndrome. Acta Med Scand 1945;158:4-122.
8 Ekbom KA: Restless legs syndrome. Neurol Minneap 1960;10:868-873.

9 Mathews WB: Iron deficiency and restless legs syndrome. BMJ 1976;1:898-899.

10 Spillane JD, Nathan PW, Kelly RE, Marsden CD: Painful legs and moving toes. Brain 1971; 94:541-556.

11 Earley CJ: Clinical practice. Restless legs syndrome. New Engl J Med 2003;348:21032109.

12 Bonati MT, Ferini-Strambi L, Aridon P, Oldani A, Zucconi M, Casari G: Autosomal dominant restless legs syndrome maps on chromosome 14q. Brain 2003;126:1485-1492. 